\title{
Diversity and potency of indigenous yeast from some palm juices for bioethanol production
}

\author{
TRIANIK WIDYANINGRUM ${ }^{1,2, v}$, SUHARJONO SUHARJONO ${ }^{3}$, TRI ARDYATI ${ }^{3}$, AULANNI'AM AULANNI'AM ${ }^{4, v \varphi}$ \\ ${ }^{1}$ Department of Biology Education, Faculty of Teacher Training and Education, Universitas Ahmad Dahlan. J1 Ringroad Selatan, Tamanan, Banguntapan, \\ Bantul 55191, Yogyakarta, Indonesia. Tel.: +62-274-563515, Fax.: +62-274-564604, `email: trianik.widyaningrum@pbio.uad.ac.id \\ ${ }^{2}$ Doctoral Program, Department of Biology, Faculty of Mathematics and Natural Sciences, Universitas Brawijaya. J1. Veteran, Malang 65145, East Java, \\ Indonesia \\ ${ }^{3}$ Department of Biology, Faculty of Mathematics and Natural Sciences, Universitas Brawijaya. Jl. Veteran, Malang 65145, East Java, Indonesia \\ ${ }^{4}$ Faculty of Veterinary Medicine, Universitas Brawijaya. Jl. Veteran, Malang 65145, East Java, Indonesia
}

Manuscript received: 17 October 2019. Revision accepted: 29 December 2019.

\begin{abstract}
Widyaningrum T, Suharjono S, Ardyati T, Aulanni'am A. 2020. Diversity and potency of indigenous yeast from some palm juices for bioethanol production. Biodiversitas 21: 318-325. Main energy source commonly used by the community comes from fossil energy, especially petroleum. The crisis of energy showed that Indonesia's fossil energy reserves are limited. Based on this fact it is important to develop alternative energy that environmentally friendly and sustain, especially bioethanol. The objective of this research was to diversity and potency of indigenous yeast from palm juice of Arenga pinnata Merr., Cocos nucifera L., Nypa fruticans Wurmb., and Borassus flabellifer L. for bioethanol production. Yeast from juice of the four species of palm was isolated using Yeast Malt Extract Agar (YMEA). Those isolates were screen base on ethanol production in coconut water media. The potential of yeast isolates was identified base on 18S DNA sequence similarity. The four potential isolates of yeast were A3A from A. pinnata, K1A from C. nucifera, N3E from $N$. fruticans, and S1A from B. flabellifer have highest production of ethanol are $8.6 \%, 14.2 \%, 9.0 \%$, and $9.2 \%$ respectively. Four potential isolates of yeast were A3A and N3E, K1A, and S1A have relationship with Saccharomyces cerevisiae NRRL Y-12632 ${ }^{\mathrm{T}}$, Pichia manshurica IFO $10726^{\mathrm{T}}$, and Candida tropicalis ATCC 20615 respectively.
\end{abstract}

Keywords: 18S DNA, bioethanol, indigenous yeast, palm juice

\section{INTRODUCTION}

Fossil fuels, especially petroleum, coal, and natural gas, are a major source of energy for most industries and are still the most important raw material for energy generation in the world. Currently, the world energy market value of about 1.5 trillion dollars is dominated by fossil fuels (Goldemberg 2006). However, these sources are no longer considered sustainable, and their availability decreases. (Shafiee and Topal 2009) predicted that oil, coal, and gas would only be sequentially left around 35, 107, and 37 years respectively. On the other hand, the use of fossil fuels as the main energy resources caused the arising of worldwide problems such as environmental pollution and global warming (Hoekman 2009; Kiran and Kumar 2014). There is inevitable depletion of the world's energy supply, there has been an increasing worldwide interest in alternative sources of energy (Ali et al. 2011). Bioethanol is one of the main renewable energy sources which is undoubtedly, a future fuel. Bioethanol has a higher octane number relative to that of gasoline alone, its use as a blender with gasoline reduces the emission of $\mathrm{CO}_{2}, \mathrm{NOx}$, and hydrocarbons after combustion. The use of ethanol shows high compression ratio and increased energy production in a combustion engine (Balan et al. 2013) Production of fuel ethanol through fermentation appears to be a potential alternative to fossil fuel and can be used as an only fuel in vehicles with devoted apparatuses or in fuel mixtures. Ethanol is presently derived from sugars, starches, and cellulosic materials. Unconventional cellulosic materials as seagrass and potato flour also produced ethanol (Rani et al. 2010; Basavaraj et al. 2013). Three main reasons for the production of bioethanol from cellulosic biomass are: (i) it is renewable, (ii) doesn't emit harsh gases like $\mathrm{CO}_{2}, \mathrm{SO}_{2}, \mathrm{NO}_{2}$ into the environment, and (iii) it holds the key factor to the economy. The low-cost fermentation substrate that can meet the demands of oil of the future is lignocellulosic biomass. The cellulose biomass consists of mainly waste of inedible cellulose fibers that form the stems and branches of most plants. Grain crops, switchgrass, crop residues like corn stalks, wheat straw, rice straw, grass dipping, and wood residues are the many forms of cellulosic biomass (Bharathiraja et al. 2014).

Nowadays bioethanol productions from cellulosic materials offer a solution to some of the recent environmental, economic, and energy problems facing worldwide (Kumar and Pushpa 2012). Bioethanol is generally produced by liquefaction and saccharification of starch using alfa-amylase and glucoamylase enzymes. The sugar slurry undergoes fermentation process by bacteria, yeast, or other fermenting microorganisms (Hanif et al. 2017). Various researches have been carried out for producing ethanol from several biomasses include micro and macroalgae (John et al. 2011), molasses (Wardani and Pertiwi (2013); Shamim et al. 2016), palm juice of Cocos nucifera (Saputra et al. 2012); palm juice of Nypa (Yenti 
2013; Muhammad et al. 2016), Palm juice of Borassus flabellifer (Naknean et al. 2010) and Sargassum (Saputra et al.2012; Borines et al. 2013; Widyaningrum et al. 2016) previous studies utilizing Saccharomyces cerevisiae to ferment of molasse and micro and macroalgae were produced ethanol 2.71-94.0 \% (John et al. 2011; Riyanti 2011; Wardani and Pertiwi 2013).

Indonesia is one of tropical countries that have many palm plantations such as Arenga pinnata Merr., Cocos nucifera L., Nypa fruticans Wurmb., and Borassus flabellifer $\mathrm{L}$. The most important product of palm is the sap or juice. The tapping process of palm sap involves the bruising of the interior of the developing inflorescences by means of a wooden mallet or tong, thereby stimulating sap flow. Sap is collected by cutting the end/tip of the inflorescences. Palm sap is rich in sugars (10-17\%) (Naknean et al. 2010). The objective of this study was to diversity and potency of indigenous yeast from palm juice of A. pinnata, C. nucifera, N. fruticans, and B. flabellifer. for bioethanol production.

\section{MATERIALS AND METHODS}

\section{Sampling of palm juice and isolation of yeast}

Palm juice of Arenga pinnata Merr. and Cocos nucifera L was taken from Samigaluh, District of Kulonprogo, Province of Yogyakarta, while Nypa fruticans Wurmb was taken from the District of Cilacap, and Borassus flabellifer L. was taken from District of Rembang, Province of Central Java, Indonesia. Each of palm juices was taken 250 $\mathrm{mL}$ (3 samples/replications) in a bottle and put in an icebox and then it was measured $\mathrm{pH}$, reducing sugar content, and ethanol levels. Sample of each palm juice as much as 25 $\mathrm{mL}$ was diluted with $225 \mathrm{~mL}$ of physiological salt as $10^{-1}$ dilution. This sample suspensions were made series dilution until $10^{-9}$. The samples suspension at each dilution was taken $0.1 \mathrm{~mL}$ inoculated into a sterile Petri dish and poured $15 \mathrm{~mL}$ of YMEA (Yeast Malt Extract Agar) medium. The culture was incubated at $25{ }^{\circ} \mathrm{C}$ for 48 hours and each type of yeast colony that grown was calculated.

Isolate of yeast was purified according to spread plate method. The colony of yeast was suspended into $10 \mathrm{~mL}$ of physiological salt and made series dilution until $10^{-6}$. Suspension of yeast $0.1 \mathrm{~mL}$ was spread by Drigalsky glass rod on the surface of YMEA medium in Petri dish. The yeast culture was incubated at $25^{\circ} \mathrm{C}$ for 48 hours (Aung et al. 2013). The pure culture of yeast was verified by Gram staining. In this research, the palm juice was characterized include $\mathrm{pH}$, ethanol content, sugar content, The data were analyzed of variance with significance different $(\alpha=0.05$ using SPSS program version 16.0 The pure yeast stock then was screened to obtain the highest potential isolates on ethanol production.

\section{Bioassay of yeast to produce ethanol}

This experiment was carried out according to Completely Randomized Design with yeast isolate and incubation time as treatments. Parameters of the experiment that observed include reducing sugars, yeast cell number, and ethanol concentration. One loop of yeast colony was inoculated into $100 \mathrm{~mL}$ of coconut water medium and it incubated at $30^{\circ} \mathrm{C}$ for $24 \mathrm{~h}$. The suspension of yeast culture with similar cell density was taken $10 \mathrm{~mL}$ inoculated into $100 \mathrm{~mL}$ of coconut water (C. nucifera). The culture was fermented at room temperature for six days (Blanco et al. 2012). The parameters of fermentation culture include sugars by DNS method (Jackson and Jayanthy 2014), cell number of yeast, and ethanol concentration was measured at $0,2,4$, and 6 day incubation time. The data was analyzed of variance with significance different $\alpha: 5 \%$ using SPSS program version 16 . If treatment gave significant effect followed by Duncan Multiple Range Test (DMRT) to determined selected isolates that having highest potency to produce ethanol.

\section{Optimization of selected yeast to produce ethanol}

This experiment was carried out according to Completely Randomized Design with treatment consist of yeast isolate and incubation time. Parameters of fermentation that observed include reducing sugars, number of yeast cells, and ethanol concentration. The selected yeast culture was inoculated 1 loop into $100 \mathrm{~mL}$ of coconut water. The yeast culture was incubated at $30^{\circ} \mathrm{C}$ for $24 \mathrm{~h}$. The suspension of yeast culture with similar cell density as much as $10 \mathrm{~mL}$ was inoculated into $100 \mathrm{~mL}$ coconut water media with varies of $\mathrm{pH}$ and reducing sugar concentration and it incubated six days (Blanco et al. 2012). The suspension of culture at 6 days fermentation, were measured of reducing sugars by DNS method (Jackson and Jayanthy 2014), cell number, and ethanol concentration. The data was analyzed of variance with $\alpha$ : $5 \%$ using SPSS program version 16. If treatment gave significant effect followed by DMRT. Based on the DMRT test, the optimum for ethanol fermentation was determined.

\section{Phylogenetic identification of yeast-based on 18S DNA Extraction of yeast chromosomal DNA}

DNA extraction was done based on (Elkins 2011). The yeast cells were grown in the liquid medium of YMEA. The yeast cells are harvested by centrifugation at 3,000 rpm for 15-30 minutes. The harvested cells were rinsed using 1 $\mathrm{mL}$ TE buffer and centrifuged 10,000 rpm for 15 minutes. The harvested cells were further broken down with $50 \mu \mathrm{L}$ lysozyme $(50 \mu \mathrm{g} / \mathrm{mL})$ then shaken to homogeneous and incubated $37{ }^{\circ} \mathrm{C}$ for $30 \mathrm{~min}$. To dissolve the membrane and enzyme proteins, GES reagent was added as much as 250 $\mu \mathrm{L}$, homogenized until completely dissolved and incubated for $10 \mathrm{~min}$ at room temperature. Supplement plus $125 \mu \mathrm{L}$ ammonium acetate $7.5 \mathrm{M}$ and placed on ice for 10 minutes. The separation of DNA from proteins and polysaccharides was done by adding $500 \mu \mathrm{L}$ chloroform to the solution, flipped 50 times, and centrifuged at 10,000 rpm for $10 \mathrm{~min}$. Once completed centrifuges will form 3 layers and the DNA is at the bottom layer. The DNA deposits are taken using a blunt pipette and placed into a new Eppendorf. To form DNA threads, into the solution DNA isopropanol adds half the volume of the DNA solution, then flipped through the visible DNA threads, centrifuged at 10,000 rpm for 5 minutes until the DNA threads settle. Furthermore, 
the precipitated DNA was washed with $70 \%$ cold ethanol, centrifuged again and the supernatant was discarded. The precipitated DNA was diluted for $10 \mathrm{~min}$, dissolved in 100 $\mu \mathrm{L} 0.2 \mathrm{X}$ TE buffer, and then the DNA concentration was measured using spectrophotometer at $260 \mathrm{~nm}$ wavelength.

\section{The 18S DNA sequence amplification}

\section{Sequence amplification of 18 S DNA with PCR}

Sequences of $18 \mathrm{~S}$ DNA were amplified using a general primer NS 1 (5'GTA GTC ATA TGC TTG TCTC 3') and NS 8 (5'TCC GCA GGT TCA CCT ACG GA3') (White et al. 1990). Amplification was performed on a $25 \mu \mathrm{L}$ reaction mixture containing $19 \mu \mathrm{L}$ sterile water, 25 green GoTaq (Promega), $2 \mu \mathrm{L}$ NS 1, $2 \mu \mathrm{L}$ NS 8, $2 \mu \mathrm{L}$ DNA. Amplicon was amplified under PCR conditions $94{ }^{\circ} \mathrm{C}$ for 3 min (initial denaturation), continued $\left(94{ }^{\circ} \mathrm{C}, 1 \mathrm{~min}\right.$ denaturation, $50{ }^{\circ} \mathrm{C}$, 1-minute annealing, $72{ }^{\circ} \mathrm{C}$, 1-minute elongation) 35 cycles and final extension at $72{ }^{\circ} \mathrm{C}, 5$ minutes. The PCR product was then electrophoresed using $1 \%$ agarose gel (Herkert et al. 2015).

\section{Sequencing and BLAST analysis of $18 S$ DNA region}

The amplicon of $18 \mathrm{~S}$ DNA sequence was purified and it was sequenced using automatic sequencing machine ABI 3130 XL Genetic Analyzer using primer 18S DNA. The sequence was aligned with the reference sequence from GenBank of the National Center for Biotechnology Information (NCBI) to construct a phylogenetic tree based on the neighbor-joining algorithm with bootstrap 1000 replication using the MEGA 7.0 (http://www. mega software.net) program (Kumar et al. 2018).

\section{RESULTS AND DISCUSSION}

\section{Sampling of Palm juice and isolation of yeast}

The sampling Palm juice of $A$. pinnata, $C$. nucifera, $N$. fruticans, B. flabellifer. found the initial condition of the palm juice produced was shown in Table 1. The initial palm juice, the lowest $\mathrm{pH}$ of the palm juice was obtained from $C$. nucifera $\mathrm{L}$, the highest reducing sugar concentration was $B$. flabellifer., the highest ethanol concentration $C$. nucifera $\mathrm{L}$, and the highest amount of yeast in $C$. nucifera The characteristic palm juices shown that $C$. nucifera has the highest ethanol concentration and the highest amount of yeast, indicating that the yeast can form ethanol. The highest sugar concentration $B$. flabellifer. palm juice, but maybe sugar in B. flabellifer. palm juice can not be changed all into ethanol because ethanol in B. flabellifer. palm juice was lower than $C$. nucifera palm juice which has a lower sugar concentration than B. flabellifer. palm juice.

The results of isolation isolate of palm juices were obtained A. pinnata Merr found 5 isolates names $\mathrm{A} 3 \mathrm{~B}$, A11E, A3A, A22A, A11B; C. nucifera found 5 isolates names K3D, K21A, K1C1, K2C, K1A; N. fruticans found 4 isolates names N3D, N3E, N1A, N3B, and B. flabellifer. palm juice found 4 isolates names S3D, S1A, S2D, S1C. The potential isolates are tested in producing ethanol with parameter days of fermentation $\left(6^{\text {th }}\right.$ day), reducing sugar concentration, $\mathrm{pH}$, and number of yeast.

\section{Bioassay of yeast to produce ethanol}

Table 1 shows that the highest ethanol concentration was obtained from palm juice of $C$. nucifera $\mathrm{L}$, so each isolate of yeast was screened with palm juice of $C$. nucifera to produce ethanol. The potency of each isolate of yeast to produce ethanol with parameter days of fermentation $(0,2,4$, and 6 days $), \mathrm{pH}$, reducing sugar concentration, and number of yeast. There were present in Figure 1.

Figure 1.A shows that during the fermentation process $\left(6^{\text {th }}\right.$ day) there was a decrease in $\mathrm{pH}$ with the largest difference of up to 0.43 (in K3D isolate) although it was not significant, this was in accordance with the opinion of (Ogbonda 2013) that a yeast, the $\mathrm{pH}$ range for growth can variously from 4 to 6 . The environment that is too acidic or alkaline causes microorganisms is difficult to adapt. During the fermentation, the $\mathrm{pH}$ changes can be caused by fermentation results which are the acids or bases that produced during the growth of microorganisms and organic components in the medium (Rahmawati 2010). The tendency of the fermentation medium increasingly acidic was caused by the ammonia used by the yeast cells as the nitrogen source was converted to $\mathrm{NH}_{4}^{+}$. The $\mathrm{NH}_{4}^{+}$ molecule will merge into the cell as R-NH3. In this process $\mathrm{H}^{+}$was left in the medium, so the longer the fermentation time the lower the $\mathrm{pH}$ of the medium (Lin et al. 2012). Based on this research, it can be seen that A. pinnata $C$. nucifera, N.fruticans, and B. flabellifer. contain indigenous yeast which able to produce bioethanol.

Table 1. The density of cell and biochemical characteristic of palm juices

\begin{tabular}{|c|c|c|c|c|c|}
\hline \multirow{2}{*}{ Parameters } & \multicolumn{4}{|c|}{ Types of palm juices } & \multirow{2}{*}{ P. value } \\
\hline & A. pinnata & C. nucifera & N. fruticans & B. flabellifer & \\
\hline \multicolumn{6}{|c|}{ B. } \\
\hline Total Plate Count (CFU/g) & $23.08 \pm 0.97 \mathrm{a}$ & $56.75 \pm 0.88 \mathrm{~d}$ & $54.28 \pm 0.98 \mathrm{c}$ & $38.2 \pm 0.3 b$ & 0.18 \\
\hline $\mathrm{pH}$ & $5.61 \pm 0.25 \mathrm{c}$ & $3.62 \pm 0.11 \mathrm{a}$ & $4.28 \pm 0.11 b$ & $4.39 \pm 0.07 b$ & 0.99 \\
\hline Sugar reduction $(\mathrm{mg} / \mathrm{mL})$ & $13.01 \pm 0.88 \mathrm{a}$ & $17.09 \pm 0.55 b$ & $33.38 \pm 0.99 \mathrm{c}$ & $43.35 \pm 0.29 \mathrm{~d}$ & 0.04 \\
\hline Etanol concentration $(\%)$ & $2.89 \pm 0.56 \mathrm{~b}$ & $4.63 \pm 0.19 c$ & $2.01 \pm 0.35 \mathrm{a}$ & $2.13 \pm 0.08 \mathrm{a}$ & 0.78 \\
\hline
\end{tabular}

\footnotetext{
Note: The same letter within each column do not differ significantly $(p>0.05)$ according to the Duncan test.
} 


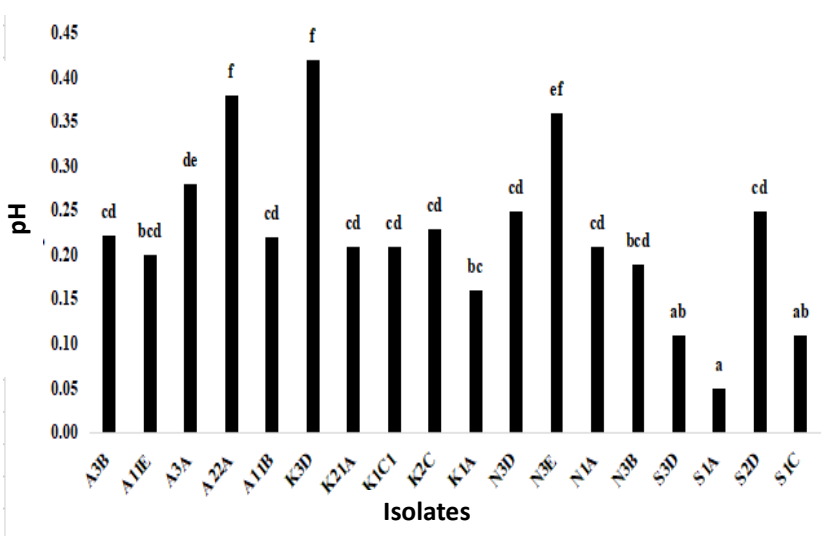

A

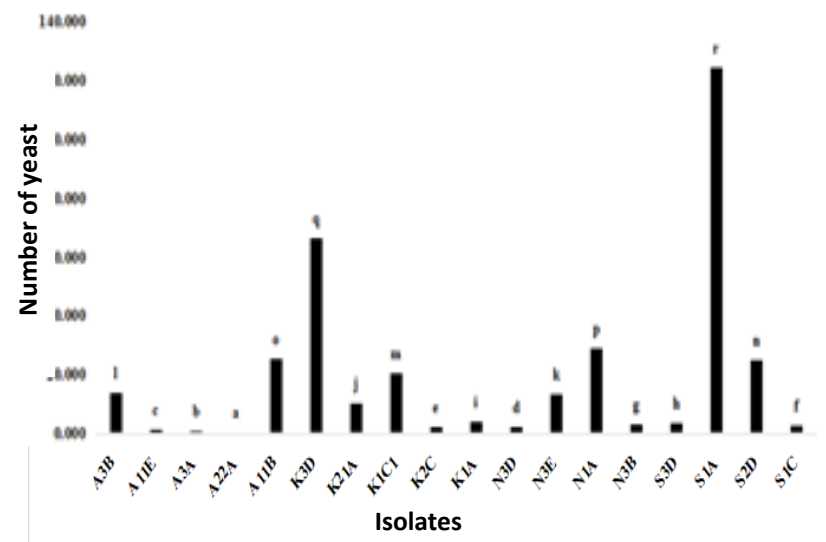

C

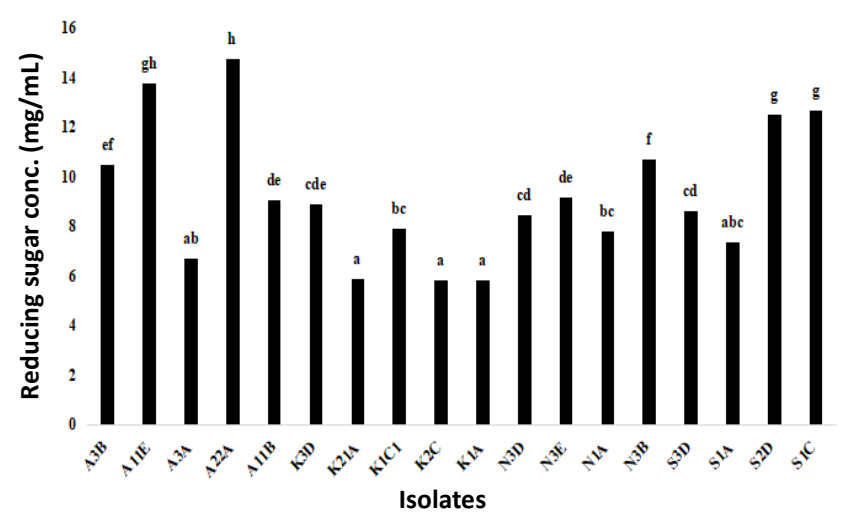

B

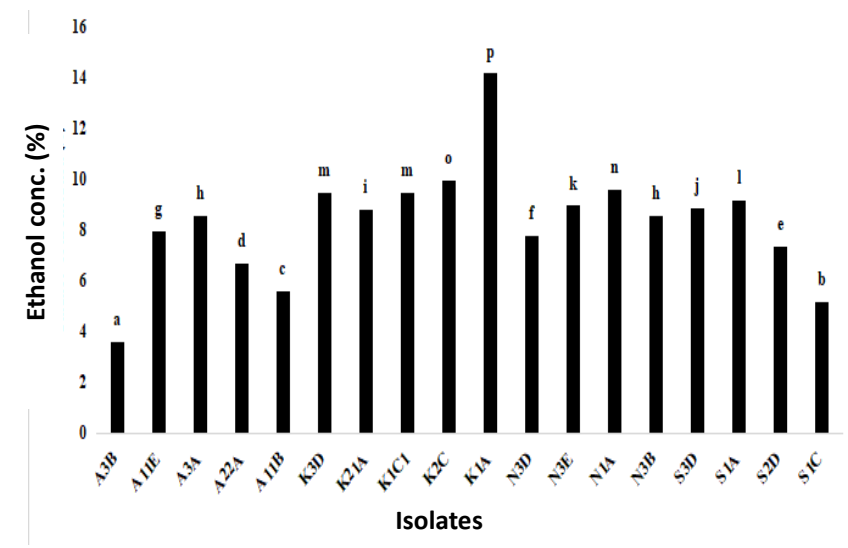

D

Figure 1. Potency of yeast isolates on ethanol production. A. The $\mathrm{pH}$ of isolates, B. Reducing sugar concentration, C. Number of yeast, D. Ethanol concentration. The same letter above each histogram show each parameter is not significantly different $(p>0.05)$ among isolates

The yeast isolates that having potency to produce ethanol on 6 days fermentation, with ten isolates of superior isolates (Figure 1.D), i.e. A3A, A11E isolates from A. pinnata, $\mathrm{K} 1 \mathrm{~A}, \mathrm{~K} 2 \mathrm{C}, \mathrm{K} 1 \mathrm{C} 1$, isolates from $C$. nucifera, N1A, N3E, N3B, isolates from $N$. fruticans, S1A and S2D isolates from B. flabellifer., with production of ethanol content of $8.6 \%, 8 \%, 14.2 \%, 10 \%, 9.5 \%, 9.6 \%$, $9 \%, 8.6 \%, 9.2 \%$, and $7.4 \%$, respectively. The days of fermentation with the highest bioethanol fermentation was 6 days, because the days time it was entering an exponential phase where the number of microbes of yeast and enzymes was secreted at the optimum amount. The longer the fermentation process, the activity of yeast as microbes which become degrading agents of sugar into bioethanol was also decreasing (Shamim et al. 2016). The lag phase was the adjustment period and the time of 6 days was the optimum time, which was exponential or logarithmic, which that bioethanol as the primary metabolite was produced, whereas after more than 6 days yeast cells enter the stationary phase and death, so that the bioethanol produced decreases (Apriwida 2013).
Fermentation time affects the growth of microorganisms. Shorter fermentation time causes inefficient fermentation due to inadequate growth of microorganisms. On the other hand, longer fermentation time gives toxic effect on microbial growth especially in batch mode due to the high concentration of ethanol in the fermented broth. Complete fermentation can be achieved at lower temperatures by using longer fermentation time which results in lowest ethanol yield. Agitation rate controls the permeability of nutrients from the fermentation broth to inside the cells and removal of ethanol from the cell to the fermentation broth. The greater the agitation rate, the higher the amount of ethanol produced. Besides, it increases the amount of sugar consumption and reduces the inhibition of ethanol on cells. The common agitation rate for fermentation by yeast cells is 150-200 rpm. Excess agitation rate is not suitable for smooth ethanol production as it causes limitations to the metabolic activities of the cells (Zabed et al. 2014). 


\section{Optimization of selected yeast to produce ethanol}

The results of the screening shown that obtained ten superior isolates, i.e. A3A, A11E isolates from A. pinnata, $\mathrm{K} 1 \mathrm{C} 1, \mathrm{~K} 1 \mathrm{~A}, \mathrm{~K} 2 \mathrm{C}$ isolates from C. nucifera, N3E, N3D, $\mathrm{N} 1 \mathrm{~A}$ isolates from $N$. fruticans, $\mathrm{S} 1 \mathrm{~A}$ and $\mathrm{S} 2 \mathrm{D}$ isolates from $B$. flabellifer, so the next step these superior isolates were tested for bioethanol produce using coconut water (assuming coconut water is part of the waste that still contains glucose) based on $\mathrm{pH}$ treatment, sugar addition, and temperature treatment, the results as shown on Figure 2.
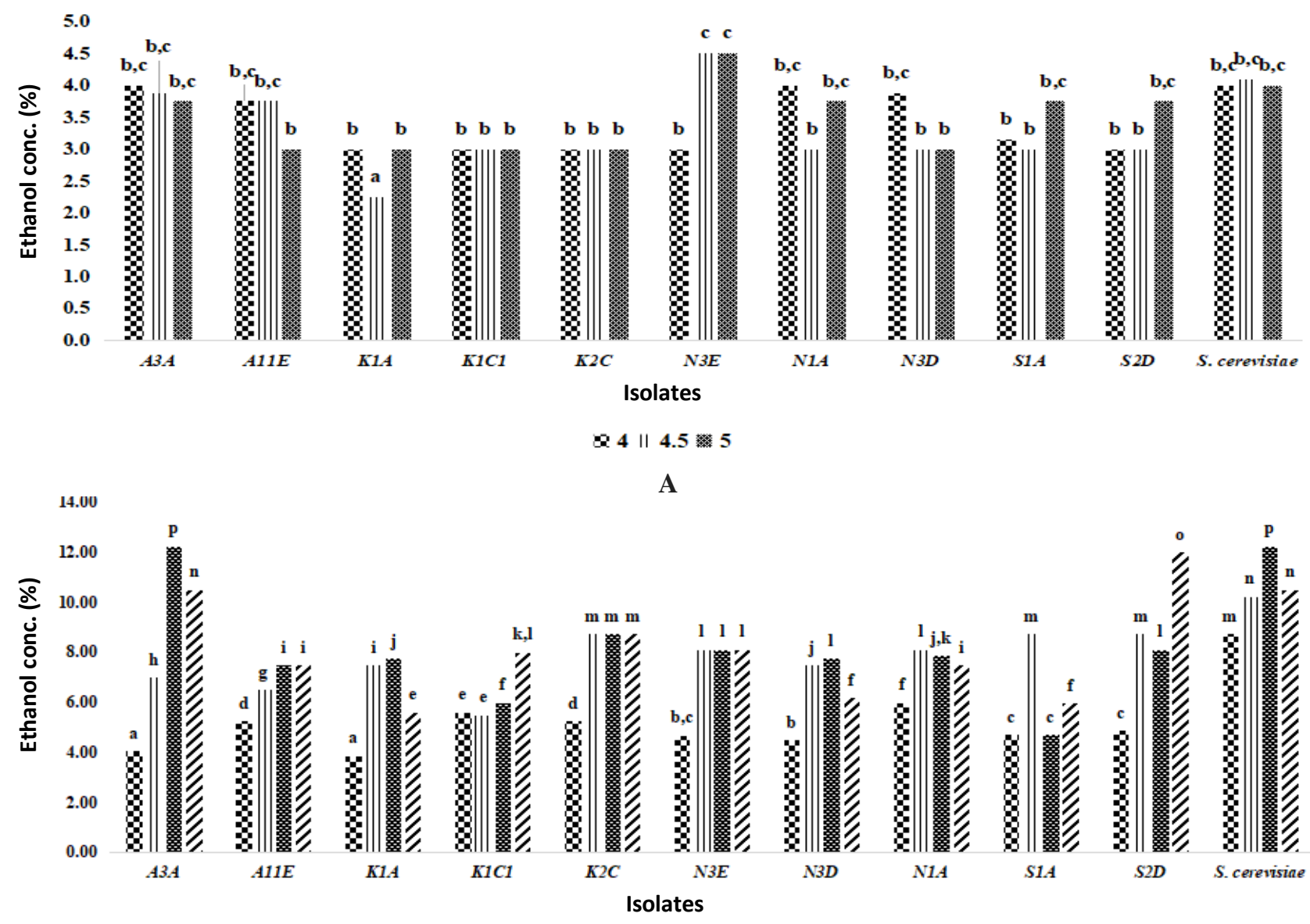

5 Control $\| 5 \%$ 舞 $10 \% \% 15 \%$

B

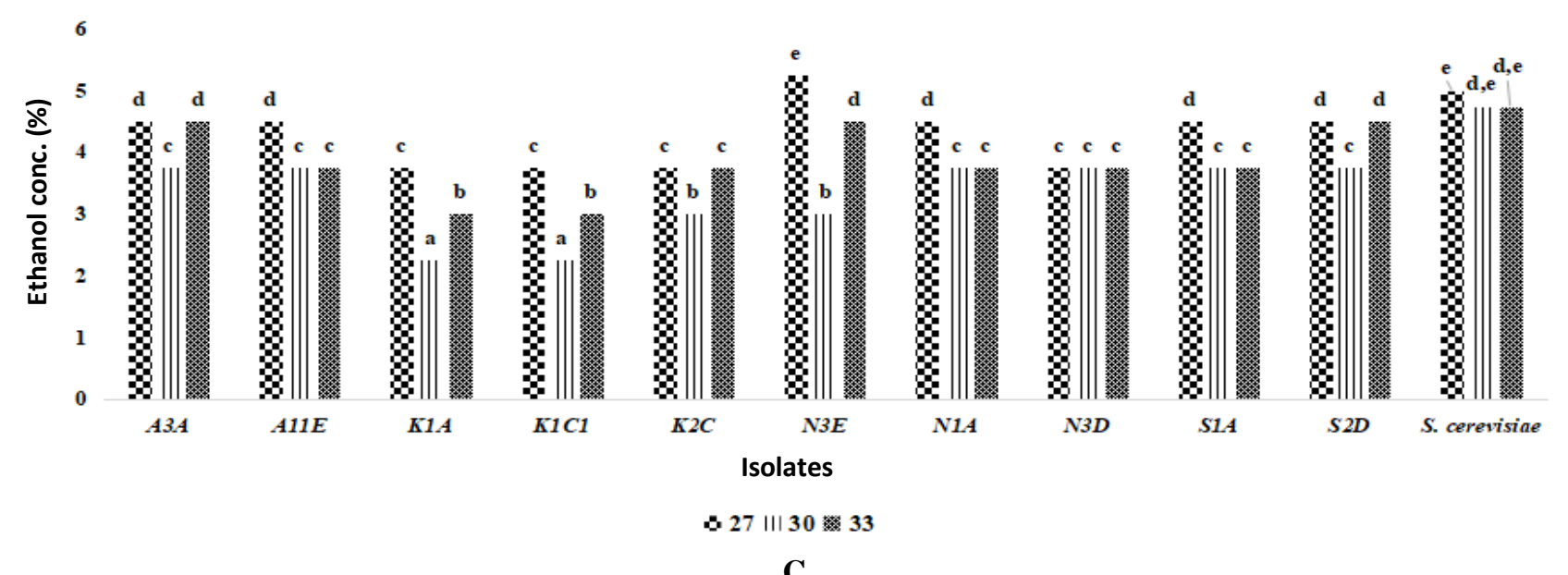

C

Figure 2. Ethanol concentration. A. pH treatment, B. Sugar concentration treatment, C. Temperature treatment. The same letter above each histogram show each parameter is not significantly different $(p>0.05)$ among isolates 
The results with $\mathrm{pH}$ treatment (Figure 2.A) shown that isolate N3E was the highest bioethanol content on $\mathrm{pH} 4.5$ and 5 (4.5\%). According to Piriya et al. (2012), optimum ethanol could be obtained if the range of $\mathrm{pH}$ for the fermentation using P.stipilis was around 4.5-5.5. Meanwhile, Narendranath (2005) explained, optimum ethanol could be achieved if the $\mathrm{pH}$ range for fermentation by S.cerevisiae was around 5.0-5.5. The result with sugar addition treatment (Figure 2.B) shown that isolate A3A was the highest bioethanol content on $10 \%$ sugar addition $(12.25 \%)$. The sugar concentration required for the optimum ethanol was $120 \mathrm{~g} / \mathrm{L}$ (P. stipitis), but S.cerevisiae the sugar concentration was relatively low. The increase in sugar concentration up to a certain level caused fermentation rate to increase. However, the use of excessive sugar concentration will cause steady fermentation rate. This is because the concentration of sugar use is beyond the uptake capacity of the microbial cells. Generally, the maximum rate of ethanol production is achieved when using sugars at a concentration of $150 \mathrm{~g} / \mathrm{L}$. The initial sugar concentration also has been considered as an important factor in ethanol production. High ethanol productivity and yield in batch fermentation can be obtained by using higher initial sugar concentration. However, it needs longer fermentation time and higher recovery costs (Zabed et al. 2014).

The result with temperature treatment (Figure 2.C) shown that isolate $\mathrm{N} 3 \mathrm{E}$ was the highest bioethanol content on $27^{\circ} \mathrm{C}(5.25 \%)$. Temperature is one of the most important parameters in the production of ethanol since enzymatic hydrolysis and glucose fermentation rates depend upon the temperature. Generally, the fermentation temperature has a greater influence on the rate of fermentation. As the fermentation temperature increases the rate of growth as well as the rate of product formation increase. But there is a limitation for bioprocesses a higher temperature may not favor the growth, the cells may die, the enzymes may denature and the rate of product formation may be affected (Umamaheswari et al. 2010).

The growth rate of the microorganisms is directly affected by the temperature (Charoenchai and Henschke 1999). High temperature which is unfavorable for cell growth becomes a stress factor for microorganisms (MarelneCot and Loret 2008). The ideal temperature range for fermentation is between 20 and $35^{\circ} \mathrm{C}$. Free cells of $S$. cerevisiae have an optimum temperature near $30^{\circ} \mathrm{C}$ whereas immobilized cells have slightly higher optimum temperature due to its ability to transfer heat from particle surface to inside the cells (Liu and Shen 2008). Moreover, enzymes which regulate microbial activity and fermentation process are sensitive to high temperature which can denature its tertiary structure and inactivates the enzymes (Phisalaphong and Srirattana 2010).

\section{Phylogenetic identification of yeast-based on 18S DNA}

The results of screening using coconut water shown that the most superior isolates producing bioethanol are A3A (A. pinnata), K1A (C. nucifera), N3E (N. fruticans), and S1A (B. flabellifer). Furthermore, to find out the name of the species from each isolate, it was identified using $18 \mathrm{~S}$ DNA with the results as shown in Figure 3.

Based on identification of the 18S DNA, isolates A3A and N3E were seen similar to Saccharomyces cerevisiae NRRL Y-12632, this indicates that the yeast of the indigenous palm juice of $A$. pinnata and $N$. fruticans had the ability to convert glucose into bioethanol better than the other isolates. It was seen that isolates $\mathrm{A} 3 \mathrm{~A}$ and N3E with $\mathrm{pH}$ treatment (Figure 2.A) shown the highest levels of bioethanol $(4.5 \%)$. In the treatment of adding $10 \%$ sugar (Figure 2.B) the A3A isolates also shown the highest level of bioethanol (12.25\%) same as control. At the temperature treatment (Figure 2.C) N3E isolate shown the highest bioethanol content $(5.25 \%)$. According Ye et al. (2016) Saccharomyces cerevisiae is a key microorganism that could produce bioethanol. Saccharomyces cerevisiae a well-established organism for bioethanol production (Mannan et al. 2018). S. cerevisiae is the most commonly employed yeast in industrial ethanol production as it tolerates a wide range of $\mathrm{pH}$ (Lin et al. 2012). According to Mussato et al. (2012) certain yeast strains such as Pichia stipitis (NRRL-Y-7124), S. cerevisiae (RL-11) and Kluyveromyces fagilis (Kf1) were reported as good ethanol producers from different types of sugars.

The results of the identification classified as valid because the index similarity was more than $95 \%$. Candida tropicalis is also found in palm juice B. flabellifer. from Thailand parallel with Kloeckera apiculata, Kloeckera japonica, Candida krusei, and Candida valida (Tuntiwongwanich and Leenanon 2009). Palm juice of Borassus is an academic from Burkina Faso, West Africa there is also yeast Candida tropicalis parallel with some other yeast-like Saccharomyces cerevisiae and Candida pararugosa (Ouoba et al. 2012).

\section{ACKNOWLEDGEMENTS}

The authors would like to thank the Directorate of Research and Development of Community, Directorate General of Research and Development Strengthening Research, Technology, and Education Ministry of Higher Education according to the funding support of the Research with the Contract Number: 109/SP2H/LT/DRPM/ 2018. 
A

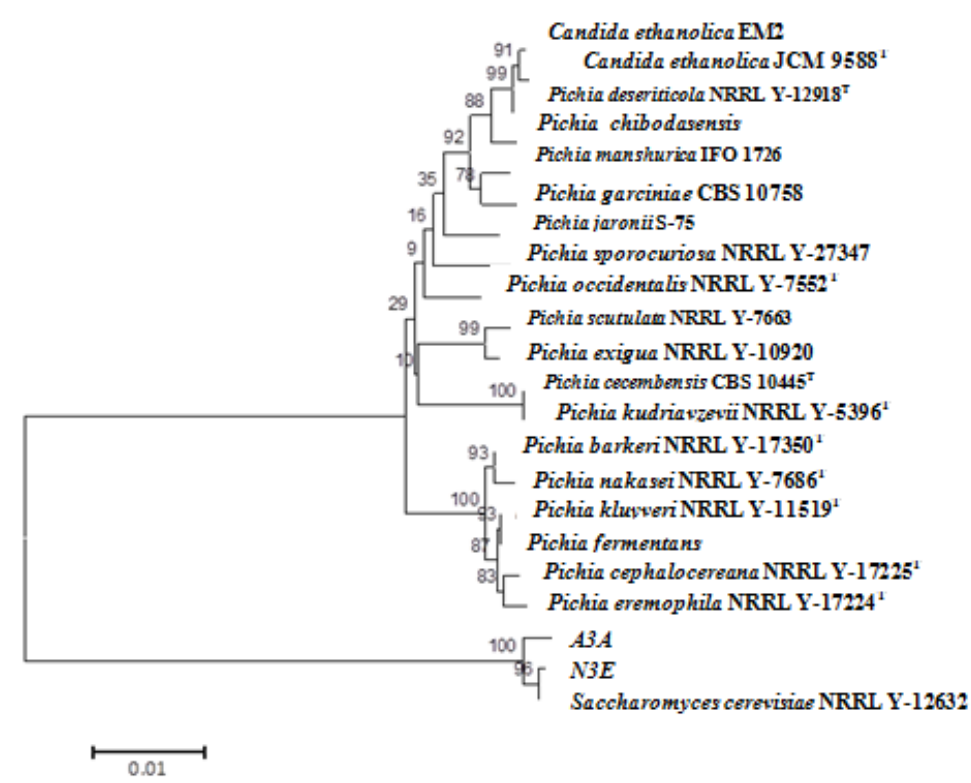

B
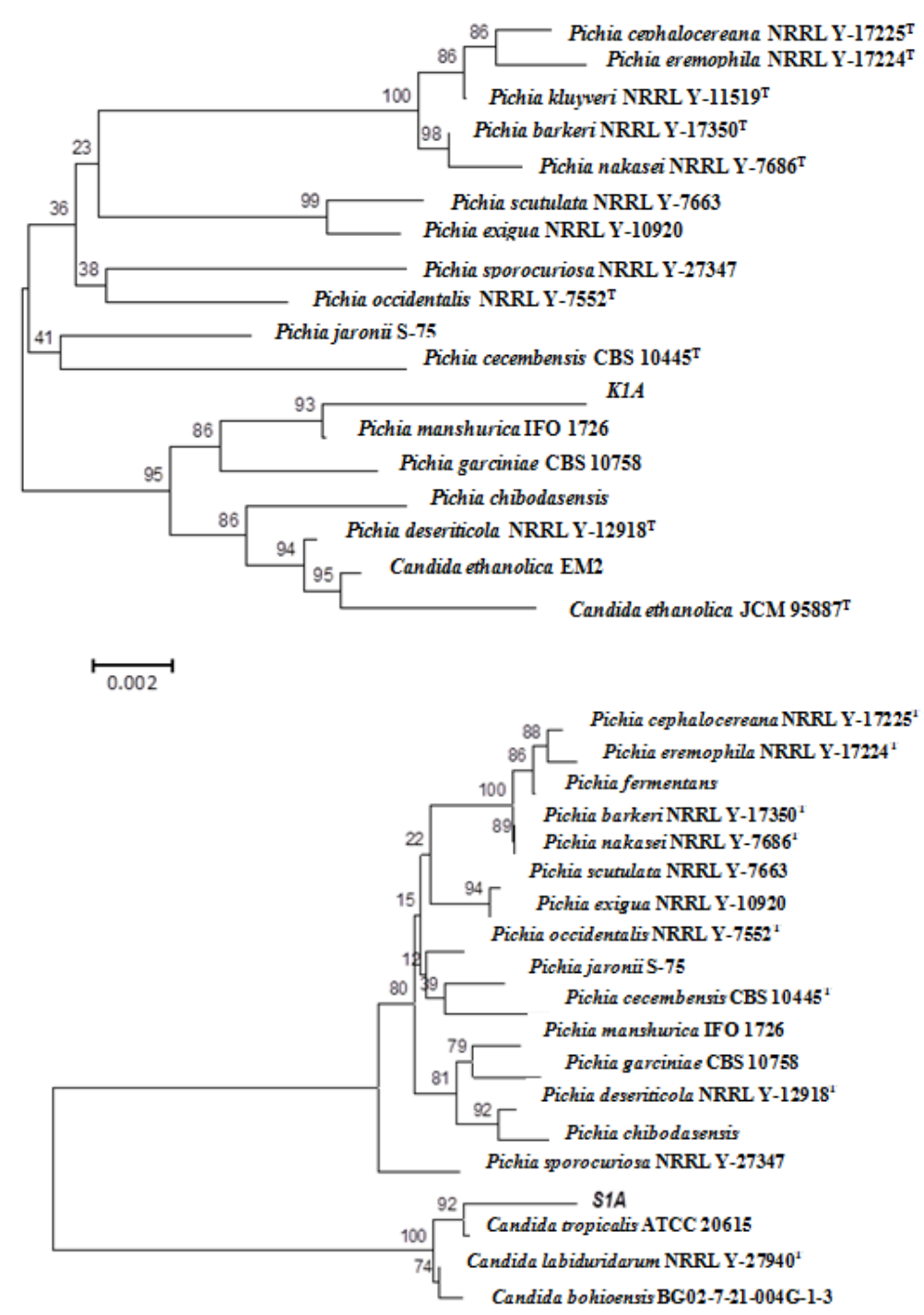

$\stackrel{\square}{0.005}$

Figure 3. Phylogenetic tree. A. Isolates A3A and N3E, B. Isolate K1A, C. Isolate S1A. The reference strain based on the 18S DNA sequence using the neighbor-joining Tamura-Nei algorithm with bootstrap 1000 replication 


\section{REFERENCES}

Ali MN, Mohd MK, Mohiuddin M. 2011. Ethanol fuel production through microbial extracellular enzymatic hydrolysis and fermentation from renewable agro-based cellulosic wastes. Intl J Pharma Bio Sci 2 (2): 321-331.

Apriwida. 2013. Study of fermentation of sweet sorghum stem (Sorghum bicolor (L) Moench) for ethanol production. J Agric Eng 1 (3): 180187.

Aung W, Watanabe Y, Hashinaga F. 2013. Isolation and phylogenetic analysis of two thermotolerant, fermentative yeast strains from liquid tapé ketan (Indonesian rice wine). Food Sci Technol Res 18 (2): 143 148.

Balan, Venkatesh USA David Chiaramonti SK. 2013. Review of US and EU initiatives toward development, demonstration, and commercialization of lignocellulosic biofuels. Biofuels Bioproducts Biorefining 8 (7): 732-759.

Basavaraj GP, Parthasarathy R, Lalith A, Ch Ravinder R. 2013. Assessing competitiveness of sweet sorghum for ethanol production: a policy analysis matrix approach. Agric Econ Res Rev 26 (1): 31-40.

Bharathiraja B, Jayamuthunagai J, Praveenkumar R, VinothArulraj J, Vinoshmuthukumar P, Saravanaraj A. 2014. Bioethanol production from lignocellulosic materials-an overview. Scitech J 1 (7): 20-29.

Blanco P, Mirás-Avalos JM, Orriols I. 2012. Effect of must characteristics on the diversity of Saccharomyces strains and their prevalence in spontaneous fermentations. J Appl Microbiol 112 (5): 936-944.

Borines MG, de Leon RL, Cuello JL. 2013. Bioethanol production from the macroalgae Sargassum spp. Bioresour Technol 138: 22-29.

Charoenchai CGH, Henschke PA. 1999. Effects of temperature, pH, and sugar concentration on the growth rates and cell biomass of wine yeasts. Amer J Enol Viticult 49 (3): 283-288.

Goldemberg J, 2006. The promise of clean energy. Energy Policy 34 (15): 2185-2190.

Elkins K. 2011. Forensic DNA Biology 1st Edition A Laboratory Manual. Academic Press, New York.

Hanif M, Mahlia HB, Aditiya MS, Abu B. 2017. Energy and environmental assessments of bioethanol production from Sri Kanji 1 cassava in Malaysia. Biofuel Res J 4 (1): 537-544

Herkert PF. Gomes RR, Muro MD, Pinheiro RL, Fornari G, Vicente VA. 2015. In vitro susceptibility and molecular characterization of Candida spp. from candidemic patients. Rev Iberoam Micol 32 (4) 221-228.

Hoekman SK. 2009. Biofuels in the U.S.-Challenges and Opportunities. Renew Energy 34 (1): 14-22.

Jackson B, Jayanthy T. 2014. Determination of sucrose in raw sugarcane juice by microwave method. Indian J Sci Technol 7 (5): 566-570.

John RP, Anisha GS, Nampoothiri KM, Pandey A. 2011. Micro and macroalgal biomass: A renewable source for bioethanol. Bioresour Technol 102 (1): 186-193.

Kiran BR, Kumar DD. 2014. Perspectives of microalgal biofuels as a renewable source of energy. Energy Conversion Manag 88 (2): 12281244.

Kumar S. Glen S, Michael L, Christina K, Koichiro T. 2018. MEGA X: Molecular evolutionary genetics analysis across computing platforms. Mol Biol Evol 35 (6): 1547-1549.

Kumar SA, Pushpa A. 2012. Saccharification by fungi and ethanol production by bacteria using lignocellulosic materials. Intl Res J Pharm 3 (5): 411-414.

Lin Y, Zhank W, Kong H. 2012. Factors affecting ethanol fermentation using Saccharomyces cerevisiae BY4742. Biomass Bioenergy 47: 395-401.

Liu R, Shen F. 2008. Impacts of main factors on bioethanol fermentation from stalk juice of sweet Sorghum by immobilized Saccharomyces cerevisiae (CICC 1308). Bioresour Technol 99: 847-854.

Mannan MA, et al. 2018. Saccharomyces cerevisiae bio-ethanol production, a sustainable energy alternative.

MarelneCot MMO, Loret JF. 2008. Physiological behaviour of Saccharomyces cerevisiae in aerated fed-batch fermentation for high level production of bioethanol. FEMS Yeast Res 7 (1): 22-32.

Muhammad Y, Hadi AB, Bello AM, Dogarai BBS. 2016. Bioethanol production from neem tree leaves (Azadirachta indica) using
Saccharomyces cerevisiae as fermenting agent. IOSR J Appl Chem 9 (3): 32-37.

Mussato EMS, Machado LM, Carneiro JAT. 2012. Sugar metabolism and ethanol production by different yeast strains from coffee industry wastes hydrolysates. Appl Energy 92: 763-768.

Naknean P, Meenune M, Roudaut G. 2010. Characterization of palm sap harvested in Songkhla province, southern Thailand. Int Food Res J 17 (4): 977-986.

Narendranath NV. 2005. Relationship between $\mathrm{pH}$ and Medium dissolved solids in terms of growth and metabolism of Lactobacilli and Saccharomyces cerevisiae during ethanol production. Appl Environ Microbiol 71 (5): 2239-2243.

Ogbonda KH. 2013. Effect of temperature and $\mathrm{pH}$ on ethanol production by a Blastomyces species isolated from the intestine of oil palm weevil (Rhynchophorus palmarum, Coleoptera). Afr J Biotechnol 12 (6): 588-591.

Ouoba L, Kando I, Parkouda C, Sawadogo-Lingani HD. 2012. The microbiology of bandji, palm wine of Borassus akeassii from Burkina Faso: Identification and genotypic diversity of yeasts, lactic acid and acetic acid bacteria. J Appl Microbiol 113 (6): 1428-1441.

Phisalaphong MN, Srirattana WT. 2010. Mathematical modeling to investigate temperature effect on kinetic parameters of ethanol fermentation. J Biochem Eng 28 (1): 36-43.

Piriya PS, Vasan PT, Padma VS, Vidhyadevi U, Archana K, Vennison SJ. 2012. Cellulosic ethanol production by recombinant cellulolytic bacteria harbouring pdc and adhII Genes of Zymomonas mobilis. Biotechnol Res Intl 2012: 817549. DOI: 10.1155/2012/817549.

Rahmawati 2010. Utilization of cassava skin waste (Manihot utilissima Pohl.) and pineapple skin (ananas comosus L.) on bioethanol production using Aspergillus niger. J Food Technol Appl Res 2 (2): 73-75.

Rani P, Sharma S, Garg FC, Raj K, Wati L. 2010. Ethanol production from potato flour by Saccharomyces cerevisiae. Indian J Sci Technol 3 (7): $733-736$

Riyanti EI. 2011. Some genes in bacteria responsible for bioethanol production. Agric Res Dev J 30 (2): 23-25.

Saputra Ridlo A, Widowati I. 2012. Study of seaweed Sargassum duplicatum J. G. Agardh as producer of bioethanol by acid hydrolysis and fermentation process. J Mar 1 (2): 145-151.

Shafiee S, Topal E. 2009. When will fossil fuel reserves be diminished? Energy Policy 37 (1): 181-189.

Shamim, Sarkar MKI, Islam MR, Hossain K, Nahar K, Roy CK, Uddin ME. 2016. Isolation of yeasts from raisins and Palm-juice and ethanol production in molasses medium. Indian J Sci Technol 9 (12). DOI: 10.17485/ijst/2016/v9i12/85509

Tuntiwongwanich S, Leenanon B. 2009. Morphology and identification of yeasts isolated from toddy palm in Thailand. J Microsc Soc Thail 23: 34-37.

Umamaheswari M, Jayakumari M, Maheswari K, Subashree M, Mala P, Sevanthi T, Manikandan T. 2010. Bioethanol production from cellulosic materials. Asian J Sci Technol 1 (1): 005-011.

Wardani, Pertiwi. 2013. Ethanol production from sugarcane drops by Saccharomyces cerevisiae forming flok (Nrrl-Y 265). Agritech 33 (2): 131-139.

White T, Bruns TD, Lee B, Taylor JW. 1990. Amplification and direct sequencing of fungal ribosomal RNA genes for phylogeneticss. In: Innis MA, Gelfand H, Sninsky JS, White TJ (eds) PCR-Protocols and applications: A Laboratory Manual. Academic Press, New York.

Widyaningrum T, Prastowo I, Parahadi,M, Prasetyo AD. 2016. Production of bioethanol from the hydrolysate of brown seaweed (Sargassum crassifolium) using a naturally $\beta$-glucosidase producing yeast Saccharomyces cerevisiae JCM 3012. Biosci Biotechnol Res Asia 13 (3): 1333-1340.

Ye W, Zhang W, Liu T, Tan G, Li H, Huang Z. 2016. Improvement of ethanol production in Saccharomyces cerevisiae by high-efficient disruption of the ADH2 gene using a novel recombinant TALEN Vector. Front Microbiol 7: 1067. DOI: 10.3389/fmicb.2016.01067.

Yenti C. 2013. Pembuatan bioetanol dari nira nipah menggunakan Sacharomyces cereviceae. Jurnal Ilmiah Sains Terapan 4 (2): 105 108. [Indonesian]

Zabed H, Golam F, Jaya NS, Mohd SA, Rosli H, Amru NB. 2014. Bioethanol production from fermentable sugar juice. Sci World J 2014: 957102. DOI: $10.1155 / 2014 / 957102$ 